\title{
FAKTOR-FAKTOR YANG MEMPENGARUHI STRUKTUR MODAL PERUSAHAAN YANG TERDAFTAR DI JAKARTA ISLAMIC INDEX PERIODE 2013-20171
}

\author{
Nisaaul Jamil \\ Departemen Ekonomi Syariah- Fakultas Ekonomi dan Bisnis-Universitas Airlangga \\ Email: nisaauljamil@gmail.com
}

\author{
Atina Shofawati \\ Departemen Ekonomi Syariah- Fakultas Ekonomi dan Bisnis-Universitas Airlangga \\ Email: atinashofawati@yahoo.com
}

\begin{abstract}
:
This study aims to determine the effect of profitability, liquidity and firm size on the capital structure of companies listed in the Jakarta Islamic Index Period 2013-2017. The research method used is quantitative approach. The data in this research is panel data. The analysis technique in this research is multiple linear regression. The results showed that simultaneously profitability, liquidity and firm size have a significant influence on capital structure. Profitability partially has a significant influence on capital structure. Liquidity and firm size have no significant effect on capital structure. The results of this study are expected to expand the knowledge that is important for practitioners and academics.
\end{abstract}

Keywords: Profitability, Liquidity, Firm Size, Capital Structure

\section{PENDAHULUAN}

\section{Latar Belakang}

Perusahaan membutuhkan dana untuk menjalankan usaha. Dana tersebut dipergunakan untuk membiayai semua pengeluaran operasional usaha tersebut. Seorang manager diberi wewenang oleh para pemegang saham untuk mengelola dan menjalankan usaha dengan sebaik mungkin, termasuk dalam mengambil keputusan dalam menentukan sumber dana yang tepat. Prinsip manajemen perusahaan menuntut agar baik dalam memperoleh maupun dalam mengelola dana harus didasarkan pada pertimbangan efisiensi dan efektivitas (Syamsiyah, 2014).

Menurut Riyanto (2001), bahwa efisiensi penggunaan dana secara langsung akan menentukan besar kecilnya tingkat keuntungan yang dihasilkan dari investasi tersebut. Manajer keuangan harus mengusahakan agar perusahaan dapat memperoleh dana yang diperlukan dengan biaya minimal dan syarat-syarat yang paling menguntungkan. Manager keuangan harus mempertimbangkan dengan cermat sifat dan biaya masing-masing sumber dana yang akan dipilih, karena masing-masing sumber dana mempunyai konsekuensi finansial yang berbeda-beda.

Setiap perusahaan harus berusaha menutupi kebutuhan dana dengan jalan memilih apakah dana diambil dari pinjaman jangka pendek, pinjaman jangka panjang atau dengan modal sendiri. Perusahaan pula harus menentukan berapa sebaiknya modal

\footnotetext{
${ }^{1}$ Jurnal ini merupakan bagian dari skripsi Nisaaul Jamil, NIM: 041114057 , yang diuji pada tanggal 18 Juli 2018.
} 
yang diambil dari pinjaman dan berapa dari modal sendiri (Manulung, 2005).

Pada prinsipnya pemenuhan dana perusahaan cenderung menggunakan modal internal perusahaan. Misal sumber dana dari laba yang tidak dibagikan, saham pemilik atau laba ditahan. Selain sumber internal, suatu perusahan dalam memenuhi kebutuhan pembiayaan usaha dengan menggunakan dana dari sumber eksternal perusahaan, yaitu sumber dana yang berasal dari pemilik, penjualan obligasi, penerbitan saham baru atau pembiayaan.

Struktur modal merupakan sumber dana perusahaan yang menjadi salah satu faktor terpenting dalam menjalankan usaha perusahaan yang bersifat permanen yang terdiri dari hutang jangka panjang dan modal sendiri. Pengukuran struktur modal dapat menggunakan debt ratio. Berhubungan dengan keputusan pendanaan perusahaan, beberapa teori yang menjelaskan struktur modal dalam perusahaan diantaranya trade-off theory, pecking order theory dan agency theory (Istiqomah, 2011).

Seperti yang sudah dijelaskan dalam Firman Allah pada QS. Al Baqarah ayat 282 tentang struktur modal:

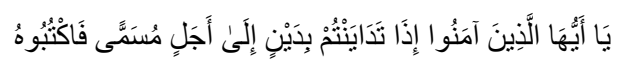

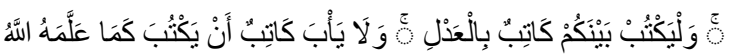

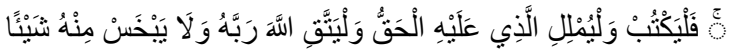

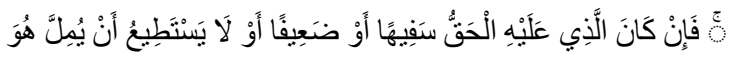

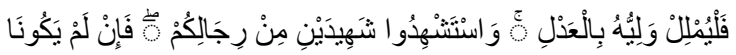

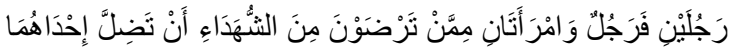

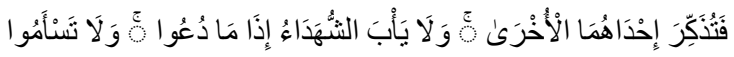

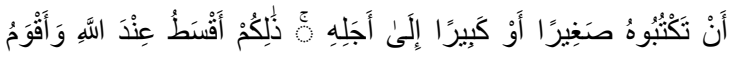

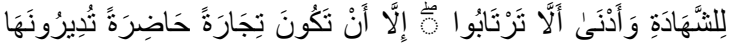

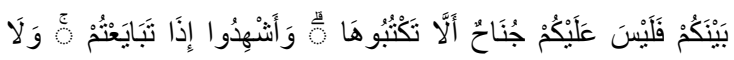

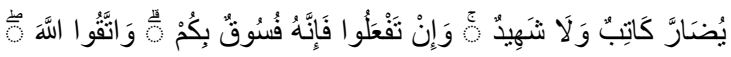

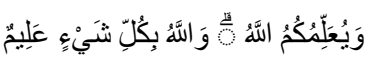

Yā ayyuhallazĩna āmanū iza tadayyantum bidainin ilā ajalin musamma faktubūh. Walyaktub bainakum kātibun bil-adli. Wa lā ya'ba kātibun an yaktuba kamā allamahullah. Fal-yaktub wal-yumlililazi 'alaihil-haqqo walyattaqillaha robbahu wa lā yabkhos minhu syai-a. Fa in kanallazi alaihil-haqqo safihan au dhoîfan aulā yastathĩu an yumillu huwa fal-yumlil waliyyuhu bil adli. Wastasyhidu syahĩdaini min rijālikum.fa in lam yakūna rojulaini farojulun wamroitāni mimman tardhouna minasyuhadaa-i an tadhilla ihdaahumaa fatuzakkiro indāhumāl ukhrő. Wa lā yakbasyuhadā-u iza mā du 'ū. Wa lā tasamū an taktubūhu shoghĩron au kabüron ilā ajalih. Zālikum aqsuthu 'indallahi wa aqwamu lisyuhadāti wa adnā allā tartābū illa an takūna tijārotan hā dlirotan turĩūunahā bainakum falaisa 'alaikum junāhun alla taktubūhā. Wasyhidū izā tabāya'tum. Wa lā yudlőrő kātibun walā syahĩd. Wa in taf'alu fa innahu fusūqum bikum. Wattaqullah. Wa yuallimukumullah. Wallahu bikulli syai-in 'alim. Artinya: "Wahai orang-orang yang beriman! Apabila kamu melakukan utangpiutang untuk waktu yang ditetukan, hendaklah kamu menulisnya. Dan hendaknya seorang penulis diantara kamu menuliskan dengan benar. Janganlah penulis menolak untuk menuliskan sebagaimana Allah telah mengajarkan kepadanya, maka 
Jamil, et al/Jurnal Ekonomi Syariah Teori dan Terapan Vol. 6 No. 4 April 2019: 704-719; FAKTOR-FAKTOR YANG MEMPENGARUHI STRUKTUR MODAL PERUSAHAAN YANG TERDAFTAR DI JAKARTA ISLAMIC INDEX PERIODE 2013-2017

hendaklah ia menuliskan. Dan hendaklah orang yang berutang itu mendiktekan, dan hendaklah dia bertaqwa kepada Allah, Tuhannya, dan janganlah ia mengurangi sedikitpun dari padanya. Jika yang berutang itu orang yang kurang akalnya atau lemah (keadaannya), atau tidak mampu mndiktekan sendiri, maka hendaknya walinya mendiktekannya dengan dua orang saksi laki-laki diantara kamu. Jika tidak ada (saksi) dua orang laki-laki, maka (boleh) seorang laki-laki dan dua orang perempuan diantara orang-orang yang kamu sukai dari para saksi (yang ada), agar jika yang seorang lupa maka yang seorang lagi mengingatkannya. Dan janganlah saksisaksi itu menolak apabila dipanggil. Dan janganlah kamu bosan menuliskannya, untuk batas waktunya baik (utang itu) kecil maupun besar. Yang demikian itu, lebih adil di sisi Allah, lebih dapat menguatkan kesaksian, dan lebih mendekatkan kamu kepada ketidakraguan, kecuali jika khal itu merupakan perdagangan tunaiyang kamu jalankan diantara kamu, maka tidak ada dosa bagi kamu jika kamu tidak menuliskannya. Dan ambillah saksi apabila kamu berjual beli, dan janganlah penulis mempersulit dan begitu juga saksi. Jika kamu lakukan (yang demikian), maka sungguh hal itu suatu kefasikan pada kamu. Dan bertaqwalak kepada Allah, Allah memberikan pengajaran kepadamu, dan Allah Maha Mengetahui sesuatu" (Kementerian Agama Republik Indonesia).
Pasar modal syariah ialah pasar yang terdiri dari berbagai instrumen keuangan atau sekuritas jangka panjang yang dapat diperjualbelikan, yaitu termasuk dalam bentuk hutang ataupun modal sendiri, baik yang diterbitkan oleh pemerintah, public authorities (otoritas negara) maupun perusahaan swasta (Suhartono dan Qudsi, 2009:6). Di Indonesia terdapat beberapa pasar modal yang aktif di Indonesia, mulai dari pasar modal konvensional hingga pasar modal yang menerapkan prinsip syariah (Nurhidayati, 2018:2).

Adanya perkembangan yang pesat pada pasar modal syariah, terdapat sejumlah instrumen keuangan yang ditawarkan pada investor yang pula memenuhi ketentuan syariah. Menurut Sutedi (2009:60) Dalam industri pasar modal, prinsip syariah telah diterapkan dalam berbagai kegiatan usaha berkaitan dengan aktivitas menghasilkan produk, yaitu instrument obligasi, saham dan fund (Reksa Dana). Prinsip-prinsip syariah dalam operasional pasar modal merupakan prinsip-prinisp yang didasari oleh ajaran agama Islam yang terdapat penetapannya dilakukan berdasarkan fatwa DSN MUI Nomor 40/DSN-MUI/X/2003 Tentang Pasar Modal dan Pedoman Umum Penerapan Prinsip Syariah di Bidang Pasar Modal.

Pasar modal syariah yang juga semakin pesat dan investasi tidak jauh dari saham. Saham merupakan adanya bukti pada kepemilikan atau penyertaan suatu perusahaan yang memberikan hasil 
Jamil, et al/Jurnal Ekonomi Syariah Teori dan Terapan Vol. 6 No. 4 April 2019: 704-719; FAKTOR-FAKTOR YANG MEMPENGARUHI STRUKTUR MODAL PERUSAHAAN YANG TERDAFTAR DI JAKARTA ISLAMIC INDEX PERIODE 2013-2017

investasi yang bergantung pada kemampuan investor dalam mengelolanya (BEI, 2014). Oleh karena itu, di Indonesia berkembangnya saham di Indonesia, PT Bursa Efek Jakarta (BEJ) bersama dengan PT DanaReksa Investment Management (DIM) meluncurkan saham syariah yaitu Jakarta Islamic Index, saham syariah yang berprinsip harus jauh dari ribawi. Dengan adanya pasar modal sendiri dapat mempermudah perekonomian lebih meningkat.

Jakarta Islamic Index memiliki 30 perusahaan yang terdaftar dan para investor menanamkan saham di perusahaan-perusahaan tersebut. Pemilihan pada kriteria perusahan untuk menyaring saham-saham yang dapat masuk pada perhitungan Jakarta Islamic Index yaitu disusun atas persetujuan melalui Dewan Pengawas Syariah. Kriteria untuk menyaring saham-saham yang masuk perhitungan Jakarta Islamic Index merupakan saham yang mempunyai proporsi kewajiban terhadap aktiva maksimal sebesar $90 \%$ dan terdapat 30 saham dengan urutan atas tingkat likuiditas rata-rata nilai perdagangan regular selama setahun (Nafik, 2009:260).

Teori trade-off menyatakan bahwa perusahaan meminjam sampai titik di mana pajak penghematan dari dolar ekstra dalam utang sama persis dengan biaya yang berasal dari peningkatan kemungkinan kesulitan keuangan. Di bawah kerangka teori trade-off, perusahaan dipandang sebagai pengaturan rasio utang terhadap ekuitas dan secara bertahap bergerak ke arah itu menunjukkan bahwa beberapa bentuk struktur modal yang optimal dapat memaksimalkan nilai perusahaan. Teori trade-off memiliki daya tarik praktis yang kuat. Ini merasionalisasi rasio utang moderat. Ini juga konsisten dengan faktafakta yang jelas, misalnya, perusahaan yang relatif aman aset berwujud cenderung meminjam lebih dari perusahaan dengan aset tidak berwujud yang berisiko (Sheikh dan Wang, 2011).

Alternatif untuk teori trade-off adalah teori pecking order dari Myers dan Majluf (1984) dan Myers (1984). Teori pecking order didasarkan pada dua hal yang menonjol asumsi. Pertama, para manajer mendapat informasi yang lebih baik tentang prospek perusahaan mereka sendiri daripada investor luar. Kedua, manajer bertindak demi kepentingan terbaik yang ada pemegang saham. Dalam kondisi ini, suatu perusahaan kadang-kadang akan melupakan hasil bersih yang positif nilai proyek jika menerima mereka memaksa perusahaan untuk mengeluarkan ekuitas yang terlalu rendah ke yang baru investor. Ini pada gilirannya memberikan alasan bagi perusahaan untuk menilai kelonggaran keuangan, seperti uang tunai besar dan kapasitas utang yang tidak terpakai. Financial Slack memungkinkan perusahaan untuk melakukan proyek proyek yang mungkin ditolak jika mereka harus mengeluarkan ekuitas baru kepada investor. Lebih secara khusus, teori 
Jamil, et al/Jurnal Ekonomi Syariah Teori dan Terapan Vol. 6 No. 4 April 2019: 704-719; FAKTOR-FAKTOR YANG MEMPENGARUHI STRUKTUR MODAL PERUSAHAAN YANG TERDAFTAR DI JAKARTA ISLAMIC INDEX PERIODE 2013-2017

pecking order memprediksi bahwa perusahaan lebih suka menggunakan pembiayaan internal bila tersedia dan pilih utang atas ekuitas ketika pendanaan eksternal diperlukan. Singkatnya, teori trade-off menggarisbawahi pajak sementara teori pecking order menekankan pada informasi asimetris (Sheikh dan Wang, 2011).

Rasio profitabilitas merupakan rasio untuk menilai kemampuan perusahaan dalam mencari keuntungan. Rasio ini juga memberikan ukuran tingkat efektivitas manajemen perusahaan. $\mathrm{Hal}$ ini ditunjukkan oleh laba yang dihasilkan dari penjulan dan pendapatan investasi. Intinya adalah penggunaan rasio ini menunjukkan efisiensi perusahaan (Kasmir, 2013:196).

Weston dan Copeland (1996:503) menyimpulkan "likuiditas menyangkut posisi kas perusahaan dan kemampuannya untuk memenuhi kewajiban yang telah jatun tempo". Likuiditas perusahaan adalah usaha perusahaan untuk membayar kewajiban jangka pendek tepat waktu.

Tinggi rendahnya (Ukuran) perusahaan akan berpengaruh pada struktur modal dengan didasarkan pada realita bahwa semakin besar suatu perusahaan mempunyai tingkat pertumbuhan penjualan yang tinggi sehingga perusahaan tersebut akan lebih berani mengeluarkan saham baru dan kecenderungan untuk menggunakan jumlah pinjaman juga semakin tinggi.
Perusahaan dengan ukuran yang lebih tinggi memiliki akses yang lebih besar untuk mendapat sumber pendanaan dari berbagai sumber, sehingga untuk memperoleh pinjaman dari kreditur akan lebih mudah karena perusahaan dengan ukuran besar akan memiliki probabilitas lebih besar untuk memenangkan persaingan dalam industri. Perusahaan dengan skala kecil di sisi lain lebih fleksibel dalam menghadapi ketidakpastian, karena perusahaan kecil lebih cepat bereaksi terhadap perubahan yang mendadak.

Literatur empiris tentang pilihan struktur modal sangat luas, terutama mengacu pada negara industri (Myers, 1977; Titman dan Wessels, 1988; Rajan dan Zingales, 1995; Wald, 1999) dan beberapa negara berkembang (Booth et al., 2001). Namun, temuannya studi empiris ini tidak mengarah pada konsensus yang berkaitan dengan signifikan faktor penentu struktur modal. Ini mungkin karena variasi dalam penggunaan hutang jangka panjang versus jangka pendek atau karena perbedaan institusional yang ada antara negara maju dan berkembang (Sheikh dan Wang, 2011).

Mengacu pada penelitian yang dilakukan oleh Sheikh dan Wang (2011), mereka menggunakan profitabilitas, likuiditas, volatilitas pendapatan, tangibilitas (struktur asset), ukuran perusahaan, perlindungan pajak nonutang (non-debt tax shield) dan peluang pertumbuhan sebagai variabel 
Jamil, et al/Jurnal Ekonomi Syariah Teori dan Terapan Vol. 6 No. 4 April 2019: 704-719; FAKTOR-FAKTOR YANG MEMPENGARUHI STRUKTUR MODAL PERUSAHAAN YANG TERDAFTAR DI JAKARTA ISLAMIC INDEX PERIODE 2013-2017

independen, sedangkan rasio hutang sebagai variabel dependen.

Peneliti mengambil variabel profitabilitas, likuiditas dan ukuran perusahaan, apakah berpengaruh terhadap struktur modal. Penelitian ini mengambil objek perusahaanperusahaan yang terdaftar di Jakarta Islamic Index periode 2013-2017 dengan harapan perusahaan-perusahaan tersebut melakukan pengungkapan secara lebih luas dalam laporan keuangannya dibandingkan dengan perusahaan yang tidak terdaftar di Jakarta Islamic Index.

Berdasarkan uraian di atas, maka judul penelitian ini adalah "Pengaruh Profitabilitas, Likuiditas, dan Ukuran Perusahaan Terhadap Struktur Modal Perusahaan Yang Terdaftar Di Jakarta Islamic Index Periode 2013-2017".

\section{Rumusan Masalah}

Berdasarkan uraian latar belakang diatas, maka rumusan masalah yang dapat diajukan pada penelitian ini adalah:

Berdasarkan uraian latar belakang di atas, jadi konflik yang akan diteliti pada skripsi ini sebagai berikut:

1. Apakah determinan struktur modal memiliki pengaruh secara parsial terhadap struktur modal pada perusahaan yang terdaftar di Jakarta Islamic Index tahun 2013-2017?

2. Apakah determinan struktur modal memiliki pengaruh secara simultan terhadap struktur modal pada perusahaan yang terdaftar di Jakarta Islamic Index tahun 2013-2017?

\section{Tujuan Penelitian}

Penelitian ini bertujuan untuk menjawab rumusan masalah yaitu untuk mengetahui apakah Profitabilitas, Likuiditas, dan Ukuran Perusahaan berpengaruh pada Struktur Modal Perusahaan yang Terdaftar di Jakarta Islamic Index Tahun 2013-2017.

\section{LANDASAN PUSTAKA}

\section{Struktur Modal}

Menurut Brigham dan Houston (2011:115) capital structure adalah struktur harga saham yang dimaksimalkan. Capital structure merupakan gabungan dari pinjaman long-term, saham preferen dan saham biasa, dan keuntungan ditahan yang dipilih perusahaan pada capital structurenya. Capital structure dipahami sebagai bagian pengeluaran long-term dari pinjaman, saham preferen dan ekuitas saham biasa.

\section{Teori Trade-Off}

$$
\text { Modigliani dan Miller }
$$
mengembangkan teori trade-off dari struktur modal. Mereka menunjukkan bahwa utang bermanfaat karena bunga dapat dikurangkan dalam menghitung pajak, tetapi utang juga menimbulkan biaya yag berhubungan dengan kebangkrutan yang aktual dan potensional. Menurut teori MM, struktur modal yang optimal berada pada keseimbangan antara manfaat pajak dari utang dan biaya yang berkaitan dengan kebangkrutan (Brigham dan Houston, 2001:45). 


\section{Teori Pecking Order}

Teori Pecking Order Myers dan Majluf (1984) dan Myers (1984). Teori pecking order didasarkan pada dua asumsi yang menonjol. Pertama, para manajer mendapat informasi yang lebih baik tentang prospek perusahaan mereka sendiri daripada investor luar. Kedua, manajer bertindak demi kepentingan terbaik pemegang saham yang ada. Dengan kondisi ini, suatu perusahan kadang-kadang akan meninggalkan proyek Net Present Value yang positif jika mereka memaksa menerima perusahaan untuk menerbitkan ekuitas yang kurang dihargai oleh investor. Hal ini pada gilirannya memberikan alasan bagi perusahaan untuk menilai kelonggaran kevangan (financial slack), seperti kas besar dan kapasitas utang yang tidak terpakai (Sheikh dan Wang:2011).

\section{Profitabilitas}

Rasio profitabilitas merupakan rasio untuk menilai kemampuan perusahaan dalam mencari keuntungan. Rasio ini juga memberikan ukuran tingkat efektivitas manajemen perusahaan. Hal ini ditunjukkan oleh laba yang dihasilkan dari penjulan dan pendapatan investasi. Intinya adalah penggunaan rasio ini menunjukkan efisiensi perusahaan (Kasmir, 2013:196).

\section{Likuiditas}

Weston dan Copeland (1996:503) menyimpulkan "likuiditas menyangkut posisi kas perusahaan dan kemampuannya untuk memenuhi kewajiban yang telah jatuh tempo".
Likuiditas perusahaan adalah usaha perusahaan untuk membayar kewajiban jangka pendek tepat waktu.

Ketidakmampuan perusahaan membayar kewajibannya terutama utang jangka pendek (yang sudah jatuh tempo) disebabkan oleh beberapa faktor. Pertama, bisa dikarenakan memang perusahaan sedang tidak memiliki dana sama sekali. Atau kedua, bisa mungkin saja perusahaan memiliki dana, namun saat jatuh tempo perusahaan tidak memiliki dana (tidak cukup) secara tunai sehingga harus menunggu dalam waktu tertentu, untuk mencairkan aktiva lainnya seperti menagih piutang, menjual suratsurat berharga, atau menjual sediaan atau aktiva lainnya (Kasmir, 2013:128).

\section{Ukuran Perusahaan}

Perusahaan maju cenderung melakukan diversifikasi usaha lebih banyak daripada perusahaan kecil atau menengah. Maka dari itu potensi kegagalan dalam menjalankan operasional perusahaan atau kemungkinan kebangkrutan akan menurun. Ukuran perusahaan tidak jarang dijadikan parameter untuk potensi kebangkrutan bagi perusahaan, ketika perusahaan dalam ukuran lebih besar pilihan lebih bisa menghadapi masalah pada usahanya.

\section{HIPOTESIS}

1. Profitabilitas, Likuiditas, dan Ukuran Perusahaan berpengaruh secara parsial terhadap Struktur Modal Perusahaan di Jakarta Islamic Index. 
2. Profitabilitas, Likuiditas, dan Ukuran Perusahaan berpengaruh secara parsial terhadap Struktur Modal Perusahaan di Jakarta Islamic Index.

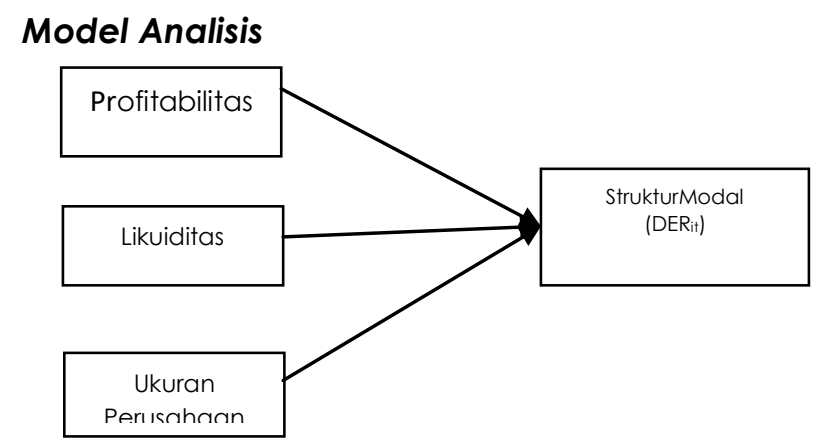

Gambar 1.

Model Analisis

Pada penelitian ini, peneliti menggunakan data panel dan untuk pengolahan data menggunakan regresi dengan metode Fixed Effect Model. Model analisis ini digunakan untuk menguji apakah profitabilitas, likuiditas, ukuran perusahaan berpengaruh signifikan terhadap struktur modal pada perusahaan yang terdaftar di Jakarta Islamic Index periode 2013-2017. Model selengkapnya adalah sebagai berikut:

$D E R i t=\beta_{0 i}+\beta_{1} P R O F_{i t}+\beta_{2} L_{L} Q_{i t}+\beta_{3} S_{I Z E_{i t}}+\mu_{i t}$

Di mana :

DER it = Struktur Modal perusahaan i pada tahun $t$.

PROF $_{\text {it }}=$ Profitabilitas perusahaan i pada tahun $t$.

$\mathrm{LIQ}_{\mathrm{it}} \quad=$ Likuiditas perusahaan i pada tahun $t$.

SIZE it = ukuran perusahaan i pada tahun t.

Bo $=$ intercept persamaan regresi.

$B_{1} B_{6}=$ koefisien regresi.

$\mu_{\text {it }} \quad=$ error perusahaan $\mathrm{i}$ pada tahun $\dagger$

\section{METODE PENELITIAN}

\section{Rancangan Penelitian}

Penelitian ini menggunaka rancangan penelitian berdasarkan pendekatan kuantitatif. Penelitian ini akan membuktikan pengaruh Profitabilitas, Likuiditas, dan Ukuran Perusahaan terhadap Struktur Modal Perusahaan yang Terdaftar di Jakarta Islamic index.

\section{Identifikasi Variabel}

Variable bebas dalam penelitian ini adalah Profitabilitas, Likuiditas, dan Ukuran Perusahaan. Sedangkan variabel terikatnya adalah Struktur Modal perusahaan di Jakarta Islamic Index.

\section{Definisi Operasional}

Variabel-variabel yang digunakan tersebut definisi operasionalnya adalah sebagai berikut:

1. Struktur Modal (DER)

Struktur modal atau rasio hutang merupakan rasio utang yang digunakan untuk mengukur perbandingan antara total utang dengan total aktiva. Dengan kata lain, seberapa besar aktiva perusahaan dibiayai oleh utang atau seberapa besar utang perusahaan berpengaruh terhadap pengelolaan aktiva. (Kasmir, 2013:156). Pada penelitian ini, struktur modal diukur dengan Debt to Equity Ratio (DER).

Rumus :

$$
\text { DER }=\frac{\text { Total Debt }}{\text { Total Asset }}
$$




\section{Profitabilitas (ROA)}

Profitabilitas merupakan rasio untuk menilai kemampuan perusahaan dalam mencari keuntungan. Rasio ini juga memberikan ukuran tingkat efektivitas manajemen suatu perusahaan. Hal ini ditunjukkan oleh laba yang dihasilkan dari penjualan dan pendapatan investasi (Kasmir, 2013:196). Pada penelitian ini, profitabilitas diukur dengan Return of Asset (ROA).

Rumus:

$R O A=$ Net Profit before Tax

$$
\text { Total Asset }
$$

3. Likuiditas (CR)

Likuiditas adalah menunjukkan kemampuan perusahaan untuk membayar utang jangka pendek atau utang yang segera jatuh tempo pada saat ditagih secara keseluruhan (Kasmir, 2013:129). Pada penelitian ini, likuditas diukur dengan Current Ratio (CR).

Rumus :

Current Ratio $=$ Current Asset

\section{Current Liabilities}

4. Ukuran Perusahaan (Ln Total Asset)

Ukuran perusahaan merupakan ukuran besar kecilnya perusahaan yang dapat dilihat dari kemampuan perusahaan dalam menghasilkan penjualan (Sheikh dan Wang, 2011). Pada penelitian ini, ukuran perusahaan diukur dengan logaritma natural dari total aset.

Rumus :

$$
\text { Size }=\text { Ln of Total Asset }
$$

\section{Jenis Dan Sumber Data}

Data yang digunakan dalam penelitian ini adalah data sekunder dan termasuk data time series. Data pada penelitian ini diperoleh dari statistik laporan kevangan yang diterbitkan di idx.co.id yang diambil periode 2013 hingga 2017

\section{Populasi Dan Sampel}

Populasi dalam penelitian ini adalah perusahaan di Jakarta Islamic Index sedangkan sampel dalam penelitian ini adalah sampel 17 data secara tahunan dengan periode 2013 hingga 2017. Metode pemilihan sampel yang digunakan dalam penelitian ini adalah metode pemilihan secara purposive sampling.

\section{Teknik Analisis}

Teknik analisis regresi data panel untuk melihat data menggunakan penggabungan time series dan cross section memiliki keunggulan daripada hanya menggunakan data time series dan cross section

\section{Estimasi Regresi Data Panel}

Uji ini dilakukan untuk dalam mengistimasi data panel terdapat tiga pendekatan yang biasa dilakukan, yaitu model Pooled Least Square (PLS), Fixed Effect Model (FEM) dan Random Effect Model (REM)

1. Pooled Least Square (PLS)

Teknik yang paling sederhana untuk mengestimasi data panel hanya dengan mengkombinasikan data time series dan cross section. Dengan hanya menggabungkan data tersebut tanpa 
melihat perbedaan antar waktu dan individu, maka dapat menggunakan metode PLS untuk mengestimasi model data panel

$$
\mathrm{Y}_{\mathrm{it}}=\alpha+\beta_{1} \mathrm{X}_{1 \text { it }}+\beta_{2} \mathrm{X}_{2} \text { it }+\beta_{3} \mathrm{X}_{3 \mathrm{it}}+\varepsilon \text { it }
$$

2. Fixed Effect Model (FEM)

Teknik model fixed effect adalah teknik mengestimasi data panel dengan menggunakan variabel dummy untuk menangkap adanya perbedaan intersep. Model ini mengasumsikan bahwa intersep adalah berbeda setiap subyek, sedangkan slope tetap sama antar subyek. Dalam membedakan satu subyek dengan subyek lainnya digunakan variabel dummy.

$Y_{\text {it }}=\alpha+\beta_{1} X_{\text {lit }}+\beta_{1} X_{\text {lit }}+\beta_{1} X_{\text {lit }}+\beta_{1} X_{\text {lit }}+\beta_{1} X_{\text {lit }}+\varepsilon_{\text {it }}$

\section{Random Effect Model (REM)}

Model ini mengestimasi data panel dimana variabel gangguan mungkin saling berhubungan antar waktu dan antar inidividu dan diasumsikan setiap subjek penelitan memiliki perbedaan intersep.

$$
\mathrm{y}_{\text {it }}=\beta_{1}+\beta_{2} \mathrm{X}_{2 \mathrm{it}}+\ldots+\beta_{n} \mathrm{X}_{\text {nit }}=\mathrm{w}_{\mathrm{it}}
$$

\section{Uji † Statistik}

Uji $t$ adalah pengujian terhadap koefisien dari variabel bebas secara parsial. Uji ini dilakukan untuk membuktikan apakah variabel independen secara individu mempengaruhi variabel dependen. Pengujian dilakukan dengan menggunakan significance level 0,05 $(a=5 \%)$

\section{Uji F-Statistik}

Uji $F$ adalah pengujian model secara keseluruhan. Oleh karena itu, uji $F$ ini lebih relevan dilakukan pada regresi berganda. Uji $F$ dilakukan untuk mengevaluasi pengaruh variabel bebas terhadap variabel terikat secara bersamasama. Pengujian dilakukan dengan menggunakan significance level 0,05 $(a=5 \%)$.

\section{Uji $\mathbf{R}^{2}$ (R-Square)}

Koefisien determinasi

digunakan untuk mengatur seberapa baik garis regresi sesuai dengan data aktualnya (goodness of fit). Selain itu, pengujian ini digunakan untuk mengukur seberapa besar persentase variabel independennya dengan melihat nilai R2 (R-square) dari hasil estimasi. Koefisien determinasi ini mengukur prosentase total variasi variabel dependen $Y$ yang dijelaskan oleh variabel dependen di dalam garis regresi. Koefisien determinasi (R2) semakin mendekati 1 maka semakin baik garis regresi dan semakin mendekati nol maka kita mempunyai garis regresi yang kurang baik.

\section{HASIL PENELITIAN DAN PEMBAHASAN}

\section{Pemilihan Model Estimasi Data Panel}

UJI Chow

Hasil uji Chow ditunjukkan oleh tabel 1 


\section{Tabel 1. \\ UJI Chow}

Redundant Fixed Effects

Tests

Pool: FEM

Test cross-section fixed effects

\begin{tabular}{lrcc}
\hline \hline Effects Test & Statistic & d.f. & Prob. \\
\hline \hline Cross-section & & & \\
F & 25.245631 & $(16,65)$ & 0.0000 \\
Cross-section & & & \\
Chi-square & 167.965648 & 16 & 0.0000
\end{tabular}

Berdasarkan hasil uji Chow pada penelitian ini adalah pada Tabel 1. diatas menunjukkan bahwa nilai $F$ probabilitasnya 0,0000 lebih kecil dari tingkat signifikansi 5\% $(a=0,05)$. Maka $\mathrm{H}_{0}$ ditolak dan $\mathrm{H}_{1}$ di diterima, sehingga model regresi data panel yang baik pada penelitian ini yaitu Fixed Effect Model (FEM).

Berdasarkan hasil pada Tabel 1, hipotesis nol ditolak sehingga model yang digunakan adalah Fixed Effect Model (FEM). Pengujian model estimasi akan berlanjut ke uji Hausman untuk kembali menentukan model terbaik yang akan digunakan, yaitu antara FEM dan REM. Hipotesis yang digunakan dalam pengujian ini adalah sebagai berikut.

$\mathrm{H}_{0}$ : model Random Effect Model (REM)

$\mathrm{H}_{1}$ : model Fixed Effect Model (FEM)

Ketentuan yang digunakan adalah jika $p$-value kurang dari a, maka analisis regresi data panel menggunakan model estimasi FEM. Sebaliknya, jika p-value lebih dari a, maka model yang digunakan adalah REM. Berdasarkan hasil pengolahan dari Eviews 7, diperoleh hasil uji Hausman sebagai berikut.

Uji Hausman

Tabel 2.

Uji Hausman

\begin{tabular}{|l|l|l|l|}
\hline Test Summary & $\begin{array}{l}\text { Chi-Sq. } \\
\text { Statistic }\end{array}$ & $\begin{array}{l}\text { Chi-Sq. } \\
\text { d.f. }\end{array}$ & Prob. \\
\hline $\begin{array}{l}\text { Cross-section } \\
\text { random }\end{array}$ & 18.457864 & 3 & 0.0004 \\
\hline \multicolumn{2}{|c|}{ Tabel menunjukkan nilai }
\end{tabular}

probabilitas sebesar 0,0004 yang artinya kurang dari nilai a 5\%. Hal ini berarti menolak $\mathrm{H}_{0}$, sehingga regresi data panel akan dianalisis menggunakan model estimasi FEM.

\section{Uji Hipotesis}

Hasil uji Fixed Effect Model (FEM) akan ditunjukkan sebagai berikut:

\section{Tabel 3.}

Dependent Variable: STRUKTUR?

Method: Pooled Least Squares

Date: 06/22/18 Time: 11:37

Sample: 20132017

Included observations: 5

Cross-sections included: 17

Total pool (balanced) observations: 85

\begin{tabular}{crrrr}
\hline \hline Variable & Coefficient Std. Error t-Statistic & Prob. \\
\hline \hline C & 0.739326 & 0.221488 & 3.337999 & 0.0014 \\
LIKUID? & -0.000210 & 0.000276 & -0.760327 & 0.4498 \\
PROFIT? & -0.011616 & 0.005184 & -2.240715 & 0.0285 \\
UKURAN? & 0.015535 & 0.011766 & 1.320323 & 0.1914 \\
Fixed Effects & & & \\
(Cross) & & & \\
_AALI-C & -0.353305 & & \\
_AKRA_C & 0.305648 & & \\
_ASII-C & 0.051839 & & \\
_BMTR_C & -0.198646 & & \\
_ICBP_C & -0.229462 & & \\
_INDF_C & 0.107007 & & \\
_INTP_C & -0.578942 & &
\end{tabular}




$$
\begin{array}{cc}
\text {-ITMG-C } & -0.394754 \\
\text { _JSMR-C } & 1.212423 \\
\text { _KLBF-C } & -0.528447 \\
\text {-LSIP-C } & -0.619529 \\
\text { _MNCN-C } & -0.286884 \\
\text { _PGAS-C } & 0.120236 \\
\text { _PTBA-C } & -0.099439 \\
\text { _TLKM-C } & -0.098188 \\
\text { _UNTR-C } & -0.293074 \\
\text { _UNVR-C } & 1.883519
\end{array}
$$

\begin{tabular}{|c|c|c|c|}
\hline \multicolumn{4}{|c|}{ Effects Specification } \\
\hline \multicolumn{4}{|c|}{ Cross-section fixed (dummy variables) } \\
\hline \multicolumn{4}{|c|}{ Mean } \\
\hline R-squared & 0.913319 & dependent var & 0.826235 \\
\hline Adjusted R- & \multicolumn{3}{|c|}{ S.D. dependent } \\
\hline squared & 0.887981 & & 0.635415 \\
\hline S.E. of & \multicolumn{3}{|c|}{ Akaike info } \\
\hline regression & 0.212668 & riterion & 0.055841 \\
\hline \multicolumn{4}{|l|}{ Sum squared } \\
\hline resid & 2.939811 & Schwarz criter & 0.518901 \\
\hline Log & \multicolumn{3}{|c|}{ Hannan-Quinn } \\
\hline \multirow[t]{2}{*}{ likelihood } & 22.37322 & riter. & 0.175337 \\
\hline & \multicolumn{3}{|c|}{ Durbin-Watson } \\
\hline F-statistic & 36.04599 & tat & 1.025921 \\
\hline \multicolumn{4}{|l|}{ Prob(F- } \\
\hline statistic) & 0.000000 & & \\
\hline
\end{tabular}

Berdasarkan Tabel 3 hasil

pengujian analisis regresi data panel menggunakan model estimasi Fixed Effect Model di atas, dapat disusun persamaan model regresi yakni:

Strukturit $_{\text {it }}=0,739326+0,0285$ Profitit + 0,4498 Likuidit $_{\text {it }}$ 0,1914Ukuranit

\section{Uji Parsial ( t-test)}

Uji parsial (Uji t) digunakan untuk menguji dan membuktikan apakah masing-masing variabel independen secara individu mempengaruhi variabel dependen.
$\mathrm{H}_{0}=$ Variabel independen secara parsial berpengaruh tidak signifikan terhadap variabel dependen

$\mathrm{H}_{1}=$ Variabel independen secara parsial berpengaruh signifikan terhadap variable dependen

Kriteria dalam penerimaan $\mathrm{HO}$ dan $\mathrm{HI}$ adalah dengan melihat nilai probabilitas ( $\mathrm{p}$-value) dari masing-masing variabel. Jika nilai probabilitas lebih kecil dari 0,05 (taraf kepercayaan 95\%) maka $\mathrm{HO}$ ditolak dan $\mathrm{HI}$ diterima Begitu juga sebaliknya. Maka hasil uji $\dagger$ dapat diambil keputusan hipotesis sebagai berikut:

1. Nilai Konstanta sebesar 0.739326 menunjukkan bahwa apabila variabel profitabilitas, likuiditas dan ukuran perusahaan besarnya nol atau konstan maka nilai struktur modal 0.739326 .

2. Variabel profitabilitas memiliki nilai probabilitas sebesar 0,0285 signifikan pada tingkat signifikasi $5 \%$ sehingga $\mathrm{H}_{1}$ diterima $\mathrm{H}_{0}$ ditolak. Hal tersebut menunjukkan bahwa variabel Profitabilitas memiliki pengaruh signifikan terhadap struktur modal.

3. Variabel likuiditas memiliki nilai probabilitas sebesar 0,4498 tidak signifikan pada tingkat signifikasi $5 \%$ sehingga $\mathrm{H}_{0}$ diterima $\mathrm{H}_{1}$ ditolak. Hal tersebut menunjukkan bahwa variabel Likuiditas memiliki pengaruh tidak signifikan terhadap struktur modal.

4. Variabel ukuran perusahaan memiliki nilai probabilitas sebesar 0,1914 tidak signifikan pada tingkat signifikasi $5 \%$ sehingga $\mathrm{H}_{0}$ diterima $\mathrm{H}_{1}$ ditolak. Hal tersebut menunjukkan bahwa variabel 
Jamil, et al/Jurnal Ekonomi Syariah Teori dan Terapan Vol. 6 No. 4 April 2019: 704-719; FAKTOR-FAKTOR YANG MEMPENGARUHI STRUKTUR MODAL PERUSAHAAN YANG TERDAFTAR DI JAKARTA ISLAMIC INDEX PERIODE 2013-2017

ukuran perusahaan memiliki pengaruh tidak signifikan terhadap struktur modal.

\section{Uji Simultan (F-test)}

Berdasarkan pada penelitian ini yang terbaik yaitu menggunakan Fixed Effect Model yaitu pada tabel 3, dilihat pada nilai probabilitas F-statistik lebih kecil dari F-tabel atau probabilitasnya lebih besar yakni sebesar 0,000000 nilai ini lebih kecil dari 0,05 dan signifikan pada tingkat kepercayaan 95\% $(a=0,05)$, sehingga $\mathrm{H}_{0}$ ditolak dan $\mathrm{H}_{1}$ diterima. Maka dapat disimpulkan bahwa variabel independen, yaitu Profitabilitas, Likuiditas, dan Ukuran Perusahaan secara bersama-sama simultan berpengaruh signifikan terhadap variabel dependen, yaitu Struktur Modal perusahaan yang terdaftar di Jakarta Islamic Index periode 2013-2017.

\section{Analisis Koefisien Determinasi $\left(\mathbf{R}^{2}\right)$}

Hasil estimasi model pada Tabel 3 menunjukkan nilai determinasi dari pengujian data. Koefisien determinasi digunakan untuk mengetahui berapa besar suatu variabel independen mempengaruhi variabel dependen.

Nilai koefisien determinasi pada model FEM sebesar 0,9133 memiliki arti bahwa sebesar 91,33\% dari variasi variabel determinan struktur modal dapat dijelaskan oleh tiga variabel yang digunakan, yaitu variabel profitabilitas, likuiditas dan ukuran perusahaan. Sisa dari nilai koefisien determinasi yaitu sebesar $8,67 \%$ dijelaskan oleh variabel-variabel lain di luar model.

\section{PEMBAHASAN}

Pengaruh secara Parsial Profitabilitas terhadap Struktur Modal

Berdasarkan hasil uji pengaruh
secara parsial (uji
menggunakan a sebesar $5 \%$, diperoleh hasil bahwa probabilitas variabel profitabilitas lebih kecil daripada a $(0,0285$ $<0,05)$. Berdasarkan nilai probabilitas tersebut, diperoleh gambaran bahwa variabel profitabilitas berada pada daerah penerimaan $\mathrm{H}_{1}$ dengan nilai koefisien regresi sebesar $-0,011616$. Hal ini berarti bahwa variabel profitabilitas memiliki pengaruh negatif dan signifikan terhadap struktur modal.

Pengaruh secara Parsial Likuiditas terhadap Struktur Modal

$\begin{array}{rlrr}\text { Berdasarkan hasil uji pengaruh } & \\ \text { secara parsial (uji } & \dagger \text { dengan }\end{array}$
menggunakan a sebesar $5 \%$, diperoleh hasil bahwa probabilitas variabel likuiditas lebih besar daripada a $(0,4498>0,05)$. Berdasarkan nilai probabilitas tersebut, diperoleh gambaran bahwa variabel likuiditas berada pada daerah penerimaan $\mathrm{H}_{0}$ dengan nilai koefisien regresi sebesar $-0,000210$. Hal ini berarti bahwa variabel likuiditas memiliki pengaruh negatif tidak signifikan terhadap struktur modal.

Pengaruh secara Parsial Ukuran Perusahaan terhadap Struktur Modal

Berdasarkan hasil uji pengaruh
secara parsial (uji t) dengan
menggunakan a sebesar $5 \%$, diperoleh
hasil bahwa probabilitas variabel ukuran
perusahaan lebih besar daripada a


Jamil, et al/Jurnal Ekonomi Syariah Teori dan Terapan Vol. 6 No. 4 April 2019: 704-719; FAKTOR-FAKTOR YANG MEMPENGARUHI STRUKTUR MODAL PERUSAHAAN YANG TERDAFTAR DI JAKARTA ISLAMIC INDEX PERIODE 2013-2017

$(0,1914 \quad>0,05)$. Berdasarkan nilai probabilitas tersebut, diperoleh gambaran bahwa variabel ukuran perusahaan berada pada daerah penerimaan $\mathrm{H}_{0}$ dengan nilai koefisien regresi sebesar 0,015535 . Hal ini berarti bahwa variabel ukuran perusahaan memiliki pengaruh positif tidak signifikan terhadap struktur modal.

\section{SIMPULAN}

Penelitian ini bertujuan untuk menguji pengaruh profitabilitas, likuiditas, dan ukuran perusahaan terhadap struktur modal perusahaan yang terdaftar di Jakarta Islamic Index Periode 2013-2017. Berdasarkan analisis penulis mengambil kesimpulan berikut ini:

1. Hasil pengujian profitabilitas yang diukur dengan menggunakan Return on Asset (ROA) terhadap struktur modal yang diukur dengan Debt to Equity Ratio (DER) menunjukkan bahwa profitabilitas berpengaruh negatif signifikan terhadap struktur modal. Sejalan dengan Teori Pecking Order dan penelitian terdahulu oleh Sheikh dan Wang (2011) dan Istiqomah (2011).

2. Hasil pengujian likuiditas yang diukur dengan Current Ratio (CR) terhadap struktur modal yang diukur dengan Debt to Equity Ratio (DER) menunjukkan bahwa likuiditas berpengaruh negatif tidak signifikan terhadap struktur modal. Sejalan dengan Teori Pecking Order dan penelitian terdahulu oleh Sheikh dan Wang (2011).

3. Hasil pengujian ukuran perusahaan yang diukur dengan Natural Logarithm of Total Asset (In Total Aset) terhadap struktur modal yang diukur dengan Debt to Equity Ratio (DER) menunjukkan bahwa ukuran perusahaan berpengaruh positif tidak signifikan terhadap struktur modal. Sejalan dengan Teori Trade-Off dan penelitian terdahulu oleh Sheikh dan Wang (2011) dan Istiqomah (2011).

4. Profitabilitas, Likuiditas dan Ukuran Perusahaan secara simultan berpengaruh signifikan terhadap Struktur Modal.

Saran yang dapat diberikan dari penelitian ini adalah:

1. Penelitian selanjutnya disarankan untuk penelitian di luar periode untuk melakukan perbandingan.

2. Penelitian ini terbatas pada pengujian variabel-variabel tertentu, diharapkan calon pemegang saham perusahaan dapat memperhatikan variabel lain yang juga berpengaruh pada kebijakan struktur modal perusahaan.

3. Agar masyarakat lebih mengetahui tentang struktur modal perusahaan dan teori-teori yang berkaitan, diharapkan masyarakat tidak terbatas dari hasil penelitian ini.

4. Bagi penelitian berikutnya, diharapkan dapat meneliti variabel yang lebih beragam yang berkaitan dengan struktur modal perusahaan sehingga menghasilkan penemuan berikutnya yang lebih variatif. 


\section{DAFTAR PUSTAKA}

Baltagi, B.H. 2001. Econometric Analysis of Panel Data. Second Edition. West Sussex. John Wiley \& Sons, LTD.

Brigham, Eugene F. Dan Joel F. Houston. 2001. Manajemen Kevangan. Jakarta : Erlangga.

Buhari, Andi. Noer Azam Achsani, Mangara Tambunan, Tubagus Nur Ahmad Maulana. 2016. The Differences of Capital Structure Based On Ownership, Variance, and Correlation : Venture Capital Firms in Indonesia. International Journal of Science : Basic and Applied Research (IJSBAR) Vol. 25, No. 3, pp 128-141.

Bursa Efek Indonesia. 2018. Laporan Tahunan (Online).

(http://www.idx.co.id/idid/beranda/perusahaantercatat// aporankevangandantahunan.asp x.) diakses 07 Mei 2018.

Istiqomah, Noor. 2011 . Determinan Struktur Modal Perusahaan Manufaktur Yang Terdaftar Di Bursa Efek Indonesia (BEI) Periode 2007-2009. Skripsi. Surabaya Fakultas Ekonomi dan Bisnis Universitas Airlangga.

Karadenis, Erdinc. Serkan Yyilmaz Kandir, Mehmet Balcilar, Yildirim Beyazid Onal. 2009. Determinants Of Capital Structure : Evidences From Turkish Lodging Companies. International Journal of Contemporary Hospitality Management. Vol. 21, Issue : 5, pp. 594-609.
Kasmir. 2013. Analisis Laporan Kevangan. Jakarta : PT. Raja Grafindo Persada.

Manulung. 2005. Pengantar Manajemen Kevangan. Yogyakarta:ANDI.

Movamer, Faris M. Abu. 2011. The Determinant of Capital Structure of Palestine-Listed Companies. The Journal Risk Finance. Vol. 12, Issue : 3, pp. 226-241.

Mufaidah. 2015. Pengaruh Struktur Modal Terhadap Harga Saham Perusahaan Pada Jakarta Islamic Index Periode 2009-2013. Skripsi. Surabaya Fakultas Ekonomi dan Bisnis Universitas Airlangga.

Permatasari, Vina Septiana. 2015. Pengaruh Ukuran Perusahaan, Profitabilitas, dan Ukuran Dewan Direksi Terhadap Index Islamic Social Reporting Pada Perusahaan Yang Terdaftar Dalam Jakarta Islamic Index Tahun 2011-2013. Surabaya Fakultas Ekonomi dan Bisnis Universitas Airlangga.

Prasetyo, Bambang dan Lina Miftahul Jannah. 2008. Metode Penelitian Kuantitatif. Jakarta: PT RajaGrafindo Persada.

Purwidyastuti, Rifka Catur. 2010. Determinan Struktur Modal IStudi Pada Perusahaan Perbankan Yang Tedaftar Di BEI 2004-2007). Skripsi. Surabaya Fakultas Ekonomi Dan Bisnis Universitas Airlangga.

Ratri, Annisa Mega dan Ari Christianti. 2017. Pengaruh Size, Likuiditas, Profitabilitas, Resiko Bisnis, dan 
Pertumbuhan Penjualan terhadap

Struktur Modal Pada Sektor Industri

Properti. JRMB Vol. 12, No. 1.

Riyanto, Bambang. 2013. Dasar-dasar Pembelanjaan Perusahaan. Edisi Keempat. Yogyakarta: BPFE.

Sheikh, Nadeem Ahmed \& Zongjun Wang. 2011. "Determinants of Capital Structure: An Empirical Study of Firms in Manufacturing Industry Of Pakistan", Managerial Finance, Vol. 37, Issue: 2, pp. 117133.

Syamsiyah. 2014. "Analisis Struktur Modal Perusahaan yang Terdaftar di Jakarta Islamic Index (JII) Tahun 2009-2013", Jurnal lqtishadia. Vol. 7 , No. 1.

Umar, Husein. 2011. Metode Penelitian untuk Skripsi dan Tesis Bisnis. Jakarta: Rajawali Press.

Weston, J. Fred \& Eugene F. Brigham. 1990. Dasar-dasar Manajemen Keuangan. Jakarta: Erlangga.

Weston, J. Fred \& Thomas E. Copeland. 1996. Manajemen Kevangan. Jakarta: Erlangga 